\title{
GROWTH OF NATIVE TREES IN TWO AGROFORESTRY SYSTEMS ${ }^{1}$
}

Maria Luiza Franceschi Nicodemo ${ }^{2}$, Marcelo Dias Muller ${ }^{3}$, Vanderley Porfírio-da-Silva ${ }^{4}$, Antônio Aparecido Carpanezzi ${ }^{4}$, José Ricardo Macedo Pezzopane ${ }^{2}$ and Waldomiro Barioni Júnior ${ }^{2}$

\footnotetext{
${ }^{1}$ Received on 09.02.2015 accepted for publication on 30.06.2016.

${ }^{2}$ Empresa Brasileira de Pesquisa Agropecuária, Centro de Pesquisa Pecuária do Sudeste, São Carlos, SP - Brasil. E-mail: <marialuiza.nicodemo@embrapa.br>,<jose.pezzopane@embrapa.br>and <waldomiro.barioni@embrapa.br>.

${ }^{3}$ Embrapa Gado de Leite, Centro Nacional de Pesquisa de Gado de Leite, Juiz de Fora, MG-Brasil. E-mail: <marcelo.muller@embrapa.br>.

${ }^{4}$ Empresa Brasileira de Pesquisa Agropecuária - CNPF, Embrapa Florestas, Embrapa Florestas, Colombo, PR - Brasil. E-mail:<vanderley.porfirio@embrapa.br>and<antonio.carpanezzi@embrapa.br>.

*Corresponding author.
}

\begin{abstract}
Agroforestry systems with eucalyptus prevail in Central and Southeast Brazil, and little information is available about systems using native trees. The aim of the present study was to evaluate the development of seven native tree species grown under two agroforestry systems. The experiment was conducted starting in 2007 in 12-hectare area in the municipality of São Carlos, São Paulo state, Brazil. The tree species planted in the two systems (a silvopastoral system and an agrisilvicultural system) were: 'capixingui' (Croton floribundus) and 'mutambo' (Guazuma ulmifolia) (tutors), 'jequitibá-branco' (Cariniana estrellensis), 'canafistula' (Peltophorum dubium) and 'ipê felpudo' (Zeyheria tuberculosa) (timber trees), and 'angico-branco' (Anadenanthera colubrina) and 'pau-jacaré' (Piptadenia gonoacantha) (N-fixing trees). Data were collected for 48 months. The results show differences among tree development, which was evaluated as growth in height and diameter, as well as sensitivity to insect and disease damage. The overall results show that the agrisilvicultural system allowed better tree development. The species with best performance in the two systems were capixingui, mutambo and canafístula. Ipê-felpudo and jequitibá-branco showed the worst results. The high variability among individuals of the same species indicates the possibility of high production advances with selective breeding of these species.
\end{abstract}

Keywords: Agroforestry; Production systems; Tropical semideciduous forest.

\section{DESENVOLVIMENTO DE ESPÉCIES FLORESTAIS NATIVAS EM DOIS SISTEMAS AGROFLORESTAIS}

\begin{abstract}
RESUMO - Sistemas de produção arborizados com eucalipto predominam no Centro e Sudeste do Brasil, com poucos dados sobre o desempenho de espécies florestais nativas nesses sistemas. O objetivo deste trabalho foi avaliar o desenvolvimento de sete espécies florestais nativas em dois tipos de sistemas de consórcio agroflorestal. O experimento foi implantado em 2007 em uma área de 12 ha, no município de São Carlos - SP. Foram plantados: capixingui (Croton floribundus) e mutambo (Guazuma ulmifolia) (tutoras); jequitibá-branco (Cariniana estrellensis), canafistula (Peltophorum dubium) e ipê-felpudo (Zeyheria tuberculosa) (madeireiras); e angicobranco (Anadenanthera colubrina) e pau-jacaré (Piptadenia gonoacantha) (fixadoras de nitrogênio) em dois tipos de sistemas de consórcio, representados por um sistema silvipastoril e um sistema silviagrícola. Os dados foram coletados durante o periodo de 48 meses. Houve diferença no desenvolvimento das árvores, avaliados por altura, diâmetro de coleto, danos por insetos e por doenças. O sistema silviagrícola propiciou maior desenvolvimento das árvores. As espécies que se destacaram, nos dois sistemas, foram capixingui, mutambo e canafistula. O ipê-felpudo e o jequitibá-branco apresentaram os piores desempenhos. A grande variabilidade apresentada entre os individuos indica a possibilidade de ganhos produtivos significativos com trabalhos de melhoramento e seleção dessas espécies.
\end{abstract}

Palavras-chave: Floresta Estacional Semidecídua; Sistemas agroflorestais; Sistemas de produção. 


\section{INTRODUCTION}

Forest production in Brazil is based both on exploitation of native forests (either for timber and charcoal or products like rubber, nuts and fruits) and forest plantations (mainly for wood to produce pulp/ paper, charcoal and timber) composed predominantly of exotic species (ABRAF, 2012). Domestic and foreign markets exist for the wood and non-lumber products obtained from native forest species, but these products mainly come from unsustainable exploitation (PENSAF, 2007). Although a considerable number of studies on native species planted in different arrangements have been carried out in Brazil, most of the information is not systematized. Additionally, most studies have focused on the Amazon region and have been restricted to the nursery phase (KANASHIRO et al., 2013).

Stock breeding has not yielded good profits for many farmers, especially smallholders, as demonstrated by the fact that $70 \%$ of pasture areas in Brazil are classified as degraded (ZIMMER et al., 2012) and by the largescale migration to cities. An alternative that has economic potential is to implement integrated production systems that combine environmental protection with more efficient land use. These systems are being encouraged by public policies, among them the federal government's ABC Program (Agricultura de Baixa Emissão de Carbono - Low Carbon Emission Agriculture), and by statelevel programs such as "Integra São Paulo”. Eucalyptus is the main tree species used in these forest systems in Central and Southeast Brazil. With the interest of producers in diversifying the forestry base by introducing native species (RUSCHEL et al., 2003; CARPANEZZI et al., 2010), other species have been tested in these systems, in both the Atlantic Forest and Amazon biomes (CARVALHO et al., 1997; DIAS, 2005; SOUCHIE et al., 2005), mainly using leguminous nitrogen-fixing species, aiming to maintain or rehabilitate pasture productivity.

The cultivation of different species in a single area means that dynamic interactions will take place among the components that change over time and in function of the characteristics of each arrangement (JOSE et al., 2004). In this respect, studying the vegetative development of woody plants composing combined systems, in different types of arrangements, is fundamental to guide the specific management practices for each situation (MÜLLER et al., 2014). Although studies have shown the potential economic advantages of planting trees associated with agricultural cultivation before (re)establishment of pasture (CARVALHO et al., 2003; VINHOLIS et al., 2010), this is not the first option of most stock breeders. In this context, a better understanding of the pros and cons of each type of combination can support decisions by rural producers. Therefore, the aim of this study was to assess the silvicultural performance of native species in a seasonal semideciduous forest area in the Atlantic Forest biome under two types of agroforestry systems.

\section{MATERIALAND METHODS}

The study was carried out in São Carlos, São Paulo (latitude $22^{\circ} 1^{\prime}$ South and longitude $47^{\circ} 53^{\prime}$ 'West). The climate in the region is classified as Cwa-Awa (KÖPPEN, 1948), with two well-defined seasons: dry from April to September; and rainy from October to March. The yearly average temperature is $21.2^{\circ} \mathrm{C}$ and the annual relative humidity is $75.6 \%$. The terrain in the region is gently rolling, with slopes of $3 \%$ to $5 \%$, and the average altitude is $860 \mathrm{~m}$. The evaluations of the agroforestry systems covered the period from April 2008 to November 2011, when the trees had reached 48 months of age since planting. The silvicultural performance of each tree species was evaluated in two agroforestry systems (classified according to Nair (1985)): a silvopastoral system and an agrisilvicultural system. The silvopastoral system (SPS) was established in December 2007, with the planting of 4,519 seedlings in an area with growth of Urochloa decumbens in dark red latosol (oxisol) (EMBRAPA, 1997) having medium texture $(699 \mathrm{~g} / \mathrm{kg}$ of sand, $232 \mathrm{~g} / \mathrm{kg}$ of clay and $69 \mathrm{~g} /$ $\mathrm{kg}$ of silt). The trees were planted in strips of three rows, spaced $17 \mathrm{~m}$ apart, following the terrain level and with distances between trees in the strip of 2.5 $\mathrm{m} \times 2.5 \mathrm{~m}$, resulting in 600 trees/ha. In the central row of the strip the following forest species were tested: 'angico-branco' (Anadenanthera colubrina); 'canafístula' (Peltophorum dubium); 'ipê-felpudo' (Zeyheria tuberculosa); 'jequitibá-branco' (Cariniana estrellensis); and 'pau-jacaré' (Piptadenia gonoacantha). For tutoring of these species, two marginal rows were planted, of 'mutambo' (Guazuma ulmifolia) and 'capixingui' (Croton floribundus). The seedlings were obtained from a local commercial nursery, and had been produced using seeds from matrix trees located within a radius of about $150 \mathrm{~km}$ of the nursery (SOUZA JUNIOR; BERNARDO, 2006). The seedlings were considered suitable for planting in the field when they reached size of $15 \mathrm{~cm}$ to $20 \mathrm{~cm}$ for propagation tubes 
of $56 \mathrm{~mL}$ (capixingui and mutambo); and from $20 \mathrm{~cm}$ to $40 \mathrm{~cm}$ for tubes of $290 \mathrm{~mL}$ (species in the center row), with a well-formed root system. The rows for planting were tilled to a depth of $30 \mathrm{~cm}$ with a sugarcane planter, after subsoiling. Before planting, each hole received $30 \mathrm{~g}$ of dolomitic limestone, $100 \mathrm{~g}$ of NPK 8-28-16 and $10 \mathrm{~g}$ ofFTE BR12. Each seedling was planted along with $2 \mathrm{~g}$ of soil conditioner (polyacrylamide gel) dissolved in $500 \mathrm{~mL}$ of water, to minimize the need for irrigation in case of dry spells. The herbicide glyphosate was applied to kill the grass 15 days before planting the seedlings in the pasture strips. The defensive measures involved combating leafcutter ants, clearing grass in the strips and crowning the seedlings, to minimize competition from invasive plants. In November 2008 each tree received $100 \mathrm{~g}$ of NPK 08-28-16 on the crown and in March 2009, $50 \mathrm{~g}$ of ammonium sulfate/plant was applied. The strips were protected from cattle by an electric fence during the entire experimental period.

The agrisilvicultural system (ACS) was established in an area dominated by Urochloa decumbens in redyellow latosol (EMBRAPA, 1997) having medium texture $(714 \mathrm{~g} / \mathrm{kg}$ of sand, $231 \mathrm{~g} / \mathrm{kg}$ of clay and $55 \mathrm{~g} / \mathrm{kg}$ of silt). A total of 2,414 seedlings were planted in January 2008, after planting of the SPS. The experimental design was analogous to that in the SPS, with strips composed of three rows of trees spaced 17 meters apart, interspersed with agricultural crops. After soil analysis, liming was performed in the entire experimental area (3.3 t/ha of dolomitic limestone, PRNT 75\%). The rows for planting were tilled to a depth of $30 \mathrm{~cm}$ with a sugarcane planter, after subsoiling. Before planting, each hole received $30 \mathrm{~g}$ of dolomitic limestone, $100 \mathrm{~g}$ of NPK 8-28-16 and $10 \mathrm{~g}$ of FTE BR12. Each seedling was planted along with $2 \mathrm{~g}$ of soil conditioner (polyacrylamide gel) dissolved in $500 \mathrm{~mL}$ of water. The trees were fertilized during the first 18 months, following the same management as in the SPS and receiving the same protective measures. The capixingui and mutambo trees in both systems were pruned in October and November 2010, 35 months after planting. The criteria for pruning were preservation of at least $50 \%$ of the green crown, with removal of branches below the point where the trunk diameter was 6 to $8 \mathrm{~cm}$.

The signal grass pastures planted between the strips of trees in the SPS received the following annual maintenance fertilization: $\mathbf{2 0 0 8}$ - dolomitic limestone
(240 kg/ha); ammonium sulfate $(240 \mathrm{~kg} / \mathrm{ha})+$ potassium chloride $(85 \mathrm{~kg} / \mathrm{ha})+$ single superphosphate $(170 \mathrm{~kg} /$ ha) + FTE BR12 (30 kg/ha); 2009 - NPK 20-05-20 (488 $\mathrm{kg} / \mathrm{ha}$ ); 2010 - ammonium sulfate (183 to $366 \mathrm{~kg} / \mathrm{ha}$ (the fertilizer application was suspended with the start of the dry season so that the paddocks did not receive the same quantity of fertilizer); and 2011 - NPK 20$05-20(732 \mathrm{~kg} / \mathrm{ha})$. The agricultural area was submitted to conventional soil preparation from planting. The liming and fertilization regimes were supported by annual soil analyses. The following crops were grown in succession: (i) forage sorghum (December 2007), fertilized initially with NPK 8-28-16 (500 kg/ha) + zinc sulfate $(20 \mathrm{~kg} / \mathrm{ha})+$ dolomitic limestone $(3.3 \mathrm{t} / \mathrm{ha})$ and then top dressed with NPK 25-00-25 (400 kg/ha), harvested in April 2008; (ii) resprouted sorghum, without fertilization, incorporated in the soil, cut in September 2008; (iii) forage corn (November 2008), after soil correction with dolomitic limestone (1.5 t/ha), initially fertilized with NPK 8-28-46 + Zn (350 kg/ha) and top dressed with NPK 20-05-20 + 0.6\% S (400 kg/ha), harvested in March 2009; (iv) pigeon pea (April 2009), fertilized with single superphosphate $(200 \mathrm{~kg} / \mathrm{ha})+$ potassium chloride (50 kg/ha), harvested in September 09/2009; (v) forage sorghum (January 2010), initially fertilized with NPK 10-20-20 (300 kg/ha) and top dressed with NPK $20-05-20+6 \% \mathrm{Zn}(500 \mathrm{~kg} / \mathrm{ha})$, harvested in May 2010; (vi) forage corn (November 2010), after soil correction with dolomitic limestone (2.5t/ha), initially fertilized with NPK 10-01-10 (470 kg/ha) and top dressed with NPK 25-0-25 (500 kg/ha), harvested in March 03/ 2011; and (vii) black oat (April 2011), initially fertilized with NPK 8-28-16 (300 kg/ha) and top dressed with ammonium sulfate $(100 \mathrm{~kg} / \mathrm{ha})$, harvested in August 2011.

Ten percent of the trees in each system were marked at the start of the experiment and repeated measures were taken. The trees were distributed in seven plots of 60 trees each in the SPS $\left(1,100 \mathrm{~m}^{2}\right)$ and five plots of 39 trees each in the ACS $\left(715 \mathrm{~m}^{2}\right)$, corresponding to one plot per strip, at random. One plot in the SPS was reduced to 40 trees due to damage caused by cattle. In November 2010, eight more trees were included in the central row in the ACS and 11 trees in the SPS, to increase the sampling intensity of this row, where there had been fewer repetitions per species. Data corresponding to the following variables were collected: height, root collar diameter and diameter at breast height.

Revista Árvore, Viçosa-MG, v.40, n.4, p.639-648, 2016

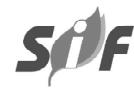


The presence of insects ( 0 - insignificant; 1 - up to $25 \% ; 2$ - up to $50 \% ; 3$ - up to $75 \% ; 4$ - more than $75 \%$ of trees damaged) and disease (0 - insignificant; 1 - up to $25 \% ; 2$ - up to $50 \% ; 3$ - up to $75 \% ; 4$ - more than $75 \%$ damaged) was evaluated on four occasions up to 18 months after planting, the period considered most critical for seedling survival.

The root collar diameter (RCD) was measured with a pachymeter or tape measure between 2 and $5 \mathrm{~cm}$ from the collar; the diameter at breast height $(\mathrm{DBH})$ corresponded to the trunk diameter at height of $1.30 \mathrm{~m}$. The calculation of the DBH for trees with multiple or bifurcated trunks, or with crown formation below the height of $1.30 \mathrm{~m}$, was done as follows: the base crosssectional area was calculated of each branch and the sum of the base areas was related to an accrued DBH value. The height was measured to the apical bud in plants with height up to $1.30 \mathrm{~m}$. For trees taller than that, the height was measured from the base to the top of the crown, using a telescopic rod. The growth rate $(\mathrm{cm} / \mathrm{month})$ was estimated by dividing the height and the RCD by the number of months since planting, considering the first measurement (month 4) and last one (month 48).

The yearly diameter increase was estimated based on the RCD, available for all measurements, rather than the DBH. The RCD at 12, 24, 36 and 48 months was estimated for each system and tree species using regression equations based on crude data. Then the diameter increase rate ( $t, \%$ ) was calculated for each yearly period according to the formula (CARNEIRO, 1973):

$$
t / 100=\frac{(D-d)}{(D+d) / 2}
$$

Where $\mathrm{D}=$ current diameter; $\mathrm{d}=$ previous diameter.

The data on height, root collar diameter and growth rate were submitted to analysis of variance (ANOVA) using the GLM procedure of the SAS program (SAS, 2010), following a 2 x 7 factorial design, considering in the model the fixed effects of system (ACS, SPS), species (angico, capixingui, canafístula, ipê, jequitibá, mutambo or pau-jacaré) and respective interaction. For comparison of multiple means, the SNK test was applied, with significance of 5\%. For analysis of the subjective variables (presence of diseases and insects), the means were transformed into $\sqrt{x+0,5}$. The difference of means was determined by the Tukey test, again at $5 \%$ significance, using the Infostat statistical package (DI RIENZO et al., 2011).

The water balance (THORNTHWAITE; MATHER, $1955)$ in the period was computed from weather data from the Embrapa Southeast Stock Breeding Research Unit (Embrapa Pecuária Sudeste) (Figure 1).

\section{RESULTS}

The growth rates of height and root collar diameter (cm/month) showed variations among the species and between the systems (Table $1, \mathrm{P}<0.05$ ). The height growth rates of capixingui and mutambo were greater in the ACS than in the SPS, but no differences were observed for the other species.

The species were classified regarding height growth rate according to the criteria proposed by Andrade et al. (2012): slow $\leq 0.70$; moderate: 0.71-1.40; fast: 1.41-2.00; and very fast $\geq 2.00$. The average height increase was greater in the ACS, classified as fast, than in the SPS, with moderate growth (Table 2). Capixingui and mutambo showed the fastest growth, pau-jacaré, canafístula and angico had moderate growth, and ipê-felpudo and jequitibá showed slow growth, irrespective of the system. There was an interaction between species and system $(\mathrm{P}<0.05)$. Angico, canafístula and ipê grew faster in the SPS, unlike the other species.

The annual diameter growth rate indicated that the growth of the trees gradually stagnated (Table 3 ).

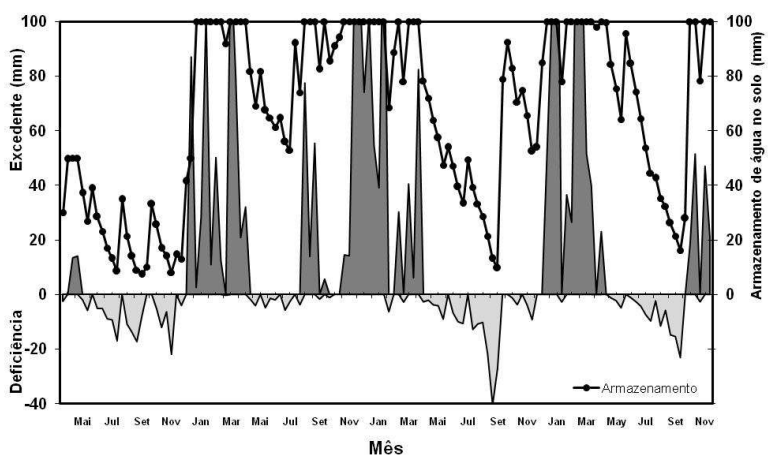

Figure 1 - Water balance diagram based on data obtained from Embrapa Pecuária Sudeste, in São Carlos, SP

Figura 1-Balanço hídrico climatológico da Embrapa Pecuária Sudeste, em São Carlos/SP. 
Table 1 - Mean, standard deviation and coefficient of variation (CV) of monthly growth rates (cm/month) of height and root collar diameter for 48 months in agrisilvicultural (ACS) and silvopastoral (SPS) systems in São Carlos, SP.

Tabela 1 - Média, desvio-padrão e coeficiente de variação (CV) das taxas de crescimento mensal (cm/mês) da altura e do diâmetro do colo até os 48 meses de implantação nos sistemas silviagrícola (SA) e silvipastoril (SSP) em São Carlos, SP.

\begin{tabular}{|c|c|c|c|c|c|c|c|c|}
\hline \multirow[t]{3}{*}{ SYSTEM } & \multicolumn{4}{|c|}{ ACS } & \multicolumn{4}{|c|}{ SPS } \\
\hline & \multicolumn{2}{|c|}{ Height } & \multicolumn{2}{|c|}{ Root collar diameter } & \multicolumn{2}{|c|}{ Height } & \multicolumn{2}{|c|}{ Root collar diameter } \\
\hline & Mean & $\mathrm{CV}$ & Mean & $\mathrm{CV}$ & Mean & $\mathrm{CV}$ & Mean & $\mathrm{CV}$ \\
\hline Angico & $6.68 \pm 3.6^{\mathrm{Ca}}$ & 53.90 & $0.10 \pm 0.05^{\mathrm{BCa}}$ & 52.81 & $8.28 \pm 3.29 \mathrm{Ca}$ & 39.68 & $0.18 \pm 0.09^{\mathrm{Ca}}$ & 50.24 \\
\hline Capixingui & $14.55 \pm 3.25^{\mathrm{Ba}}$ & 22.37 & $0.37 \pm 0.11^{\mathrm{Aa}}$ & 30.45 & $13.11 \pm 2.77^{\mathrm{Ab}}$ & 21.10 & $0.30 \pm 0.09^{\mathrm{Ab}}$ & 29.20 \\
\hline Canafístula & $6.44 \pm 3.49^{\mathrm{Ca}}$ & 54.20 & $0.10 \pm 0.06^{\mathrm{BCa}}$ & 61.15 & $5.17 \pm 2.61 \mathrm{DEa}$ & 50.43 & $0.10 \pm 0.06^{\mathrm{Da}}$ & 59.82 \\
\hline Ipê & $3.29 \pm 2.27 \mathrm{Da}$ & 69.14 & $0.06 \pm 0.05^{\mathrm{BCa}}$ & 73.20 & $3.94 \pm 2.54 \mathrm{Ea}$ & 64.49 & $0.08 \pm 0.05^{\mathrm{Da}}$ & 58.03 \\
\hline Jequitibá & $2.56 \pm 2.68^{\mathrm{Da}}$ & 104.92 & $0.04 \pm 0.03^{\mathrm{Ca}}$ & 79.50 & $1.45 \pm 1.02^{\mathrm{Fa}}$ & 69.90 & $0.03 \pm 0.02^{\mathrm{Ea}}$ & 59.19 \\
\hline Mutambo & $16.00 \pm 1.77 \mathrm{Aa}$ & 11.08 & $0.36 \pm 0.08^{\mathrm{Aa}}$ & 21.27 & $11.87 \pm 2.94 \mathrm{Bb}$ & 24.75 & $0.27 \pm 0.08^{\mathrm{Bb}}$ & 27.99 \\
\hline Pau-jacaré & $6.85 \pm 4.2^{\mathrm{Ca}}$ & 61.37 & $0.13 \pm 0.10^{\mathrm{Ba}}$ & 77.31 & $6.29 \pm 2.67 \mathrm{Da}$ & 42.45 & $0.11 \pm 0.04^{\mathrm{Da}}$ & 37.53 \\
\hline Means & $12.79 \pm 5.23^{\mathrm{a}}$ & 40.88 & $0.17 \pm 0.01^{\mathrm{a}}$ & 50.67 & $10.07 \pm 4.55^{\mathrm{b}}$ & 45.19 & $0.15 \pm 0.00^{\mathrm{a}}$ & 51.97 \\
\hline
\end{tabular}

Different capital letters in a column and different lowercase letters in a row indicate significant differences (Snedekor test, $\mathrm{P}<0.05$ ).

Table 2 - Mean and standard deviation of annual height increase, AHI (m/yr) by species and system for 48 months of agrisilvicultural (ACS) and silvopastoral (SPS) systems in São Carlos, SP.

Tabela 2 -Média e desvio-padrão de Incremento médio anual em altura, IMA-H (m/ano), por espécie e por sistema até os 48 meses nos sistemas silviagrícola (SA) e silvipastoril (SSP) em São Carlos, SP.

\begin{tabular}{|c|c|c|c|c|c|c|}
\hline \multirow[t]{3}{*}{ AHI } & \multicolumn{4}{|c|}{ Systems } & \multirow{3}{*}{$\begin{array}{l}\text { Mean of the } \\
\text { Mean } \pm \text { SD }\end{array}$} & \multirow{3}{*}{$\begin{array}{l}\text { Growth } \\
\text { species }\end{array}$} \\
\hline & \multicolumn{2}{|c|}{ ACS } & \multicolumn{2}{|c|}{ SPS } & & \\
\hline & Mean \pm SD & Growth & Mean \pm SD & Growth & & \\
\hline Angico & $0.95 \pm 0.55^{\mathrm{Db}}$ & Moderate & $1.00 \pm 0.45^{\mathrm{Da}}$ & Moderate & $0.98 \pm 0.47^{\mathrm{D}}$ & Moderate \\
\hline Capixingui & $1.69 \pm 0.50^{\mathrm{Ba}}$ & Fast & $1.56 \pm 0.67^{\mathrm{Ab}}$ & Fast & $1.60 \pm 0.62^{\mathrm{A}}$ & Fast \\
\hline Canafístula & $0.89 \pm 0.41^{\mathrm{Eb}}$ & Moderate & $0.93 \pm 0.43^{\mathrm{Ea}}$ & Moderate & $0.92 \pm 0.43^{\mathrm{E}}$ & Moderate \\
\hline Ipê & $0.38 \pm 0.23^{\mathrm{Gb}}$ & Slow & $0.46 \pm 0.30^{\mathrm{Ga}}$ & Slow & $0.44 \pm 0.29^{\mathrm{G}}$ & Slow \\
\hline Jequitibá & $0.57 \pm 0.39^{\mathrm{Fa}}$ & Slow & $0.47 \pm 0.36^{\mathrm{Fb}}$ & Slow & $0.50 \pm 0.37^{\mathrm{F}}$ & Slow \\
\hline Mutambo & $1.82 \pm 0.51^{\mathrm{Aa}}$ & Fast & $1.50 \pm 0.55^{\mathrm{Bb}}$ & Fast & $1.60 \pm 0.56^{\mathrm{B}}$ & Fast \\
\hline Pau-jacaré & $1.15 \pm 0.66^{\mathrm{Ca}}$ & Moderate & $1.11 \pm 0.56^{\mathrm{Cb}}$ & Moderate & $1.13 \pm 0.60^{\mathrm{C}}$ & Moderate \\
\hline Mean of the & $1.45 \pm 0.68^{\mathrm{a}}$ & Fast & $1.26 \pm 0.67^{\mathrm{b}}$ & Moderate & & \\
\hline
\end{tabular}
system

Letras maiúsculas distintas nas colunas e letras minúsculas distintas nas linhas indicam diferença significativa entre médias pelo teste de médias de Snedekor $(\mathrm{P}<0,05)$. Different capital letters in a column and different lowercase letters in a row indicate significant differences (Snedekor test, $P<0.05$ )

Table 3 - Mean annual diameter growth rates (\%) of tree species for 48 months in agrisilvicultural (ACS) and silvopastoral (SPS) systems in São Carlos, SP.

Tabela 3 - Taxa de acréscimo diametral anual (\%) de espécies arbóreas até os 48 meses de implantação nos sistemas silviagrícola (SA) e silvipastoril (SSP) em São Carlos, SP.

\begin{tabular}{lccccccc}
\hline Species & \multicolumn{3}{c}{ ACS } & & \multicolumn{3}{c}{ SPS } \\
\cline { 2 - 4 } & $\begin{array}{c}12-24 \\
\text { months }\end{array}$ & $\begin{array}{c}24-36 \\
\text { months }\end{array}$ & $\begin{array}{c}36-48 \\
\text { months }\end{array}$ & & $\begin{array}{c}12-24 \\
\text { months }\end{array}$ & $\begin{array}{c}24-36 \\
\text { months }\end{array}$ & $\begin{array}{c}36-48 \\
\text { months }\end{array}$ \\
\hline Angico & 19.00 & 10.80 & 7.54 & & 21.09 & 11.44 & 7.85 \\
Capixingui & 20.35 & 11.22 & 7.74 & & 19.24 & 10.87 & 7.58 \\
Canafístula & 9.54 & 6.91 & 5.41 & & 9.49 & 6.88 & 5.40 \\
Ipê-felpudo & 15.09 & 9.41 & 6.84 & & 13.24 & 8.65 & 6.43 \\
Jequitibá-branco & 8.45 & 6.32 & 5.04 & & 7.20 & 5.59 & 4.57 \\
Mutambo & 18.32 & 10.57 & 7.43 & & 16.42 & 9.91 & 7.10 \\
Pau-jacarén & 20.00 & 11.11 & 7.69 & & 13.28 & 8.67 & 6.44 \\
\hline
\end{tabular}


The incidence of insects in the SPS was higher than in the ACS $(\mathrm{P}<0.05)$, but there was no difference between the two systems regarding diseases $(\mathrm{P}>0.05)$. Mutambo (0.79 \pm 0.50$)$, capixingui $(0.70 \pm 0.53)$ and jequitibá $(0.71 \pm 0.67)$ were the species most vulnerable to insect attack, while jequitibá $(0.34 \pm 0.48)$, ipê $(0.24 \pm 0.43)$ and capixingui $(0.30 \pm 0.49)$ showed the most severe disease symptoms $(\mathrm{P}<0.05)$. The average damaged portion was generally below $25 \%$ of the plant. However, the incidence of gall in mutambo reached $45 \%$ of the trees in the agricultural area and in the silvopastoral system according to inspection in August 2009. In this same inspection, the presence was also observed of insects on the trunks of $22 \%$ and $13 \%$ of the canafístula trees examined in the agrisilvicultural and silvopastoral systems, respectively. Gall material and insects were collected and sent to PESAGRO (Rio de Janeiro State Agricultural Research Agency) for identification.

\section{DISCUSSION}

The species with the best development were capixingui and mutambo, both classified as fast growing species (Table 2). The species in the central row, which were chosen from the list of fast growers (average yearly increment (AYI) $>14 \mathrm{~m}^{3} /$ ha/year) compiled by Carvalho (2003), presented slow to moderate development. In turn, CATIE (1991) considered the growth of mutambo to be relatively slow, but stressed that the best results were obtained with annual rainfall between 900 and $1,500 \mathrm{~mm}$ and a well-defined dry season, exactly the conditions of this study. The native species cultivated in the silvopastoral and agrisilvicultural systems showed growth rates below those reported by Carvalho (2003, 2006), except for capixingui. The height increase of capixingui was near that reported by Pereira et al. (1999) for exemplars aged 39 months $(15 \mathrm{~cm} / \mathrm{month})$, although the rate of root collar diameter increase was slightly lower $(0.27 \mathrm{~cm} / \mathrm{month})$, especially compared to the agrisilvicultural system (Table 1). In another study of environmental rehabilitation, capixingui presented development similar to that observed in the present study, $13.1 \mathrm{~cm} /$ month, when planted on the lower third of a hillside(OLIVEIRA, 2011). The same author observed height increases ranging from 1.1 to $12 \mathrm{~cm} / \mathrm{month}$ for pau-jacaré, depending on the topographic position. In general, the growth of the 70 species native to the dense ombrophilous forest area studied, evaluated for six months after planting, reached up to $5 \mathrm{~cm} / \mathrm{month}$, corresponding to $93.7 \%$ of the species in the lowland,
$72.4 \%$ in the lower third and $90.3 \%$ in the middle/upper thirds of the hillside. The seedlings in that study were planted at the start of the rainy season, after soil preparation and fertilization.

The species with the lowest development in the present study were ipê-felpudo and jequitibá, both of which are classified as secondary to climax species. Pau-jacaré, angico and canafístula were in intermediate position (Tables 1 and 2), classified as having moderate growth. Of particular note is the variability of the height and diameter values found within species (Table 1), especially for jequitibá. In the last assessment of jequitibá (48 months after planting), individuals were measured with heights ranging from 0.15 to $3.63 \mathrm{~m}$. This large variability reflects the origin of the material used in the experiment. While the exotic species typically grown in planted forests, such as eucalyptus, have undergone intense selective improvement processes, the seedlings of native species available from commercial nurseries are normally produced to supply material for environmental recovery, where the aim is to increase biodiversity. This biodiversity is also expressed in genetic variability, so that the focus is on planting individuals that represent the species' natural diversity. Article 2 of the UN Convention on Biological Diversity defines biodiversity, or "biological diversity", as "the variability among living organisms from all sources including, inter alia, terrestrial, marine and other aquatic ecosystems and the ecological complexes of which they are part; this includes diversity within species, between species and of ecosystems." In choosing matrix plants for a program to produce seedlings for reforestation, the focus is on the greatest amplitude of traits, not on choosing matrixes with traits desirable for forest production. This variability is fundamental for genetic selection for purposes of improving productivity. According to Carvalho (2003), it is possible to increase the wood yield of native forest species by $20 \%$ just through expansion (and selection) of the genetic base.

Although the high variability of the species planted in the central row is interesting from the standpoint of selective breeding, this characteristic is a drawback for use in production systems. Homogeneous development of trees facilitates their management, one of the reasons for the strong interest in the use of clones. In silvopastoral systems, the young trees need to be protected from livestock until they reach appropriate 
size to coexist with the animals without suffering severe damage. The presence of plants with highly distinct characteristics makes it hard to determine the proper moment to allow animals to enter the system.

The species evaluated showed apical dominance. This characteristic facilitates management (including use of machinery) and entry of light and wind. Although having high insertion, the branches of the capixingui trees tended to grow downward, causing problems in the agrisilvicultural system, where they hampered the passage of tractors, especially ones with cabs, under the crown. Although it is possible to cut the branches, this is not a desirable option since it would add effort, discouraging the use of this species in more mechanized systems.

Mutambo and capixingui were the two species that performed best in this study. Capixingui outperformed mutambo in the SPS, but when the fertility conditions were more favorable, mutambo surpassed capixingui in growth rate (height and diameter). Mutambo is a deciduous species, which can shed leaves intensely under water stress conditions. Although leaf loss during dry periods is a water-saving reaction of plants, this process represents a large loss of nutrients. Complete leaf loss is especially evident in more fertile (richer) environments, where plants can quickly recover the lost nutrients from the soil (JARAMILLO; SANFORD, 1995, cited by NUNES et al., 2005). Therefore, the recovery of the mutambo trees under the conditions of the SPS was not as good as that observed in the ACS, which allowed the trees to develop in compatibility with the richer site.

All the species studied are on the lists of forest species indicated for economic use. The five species planted in the central row are on the list of 32 fastgrowing native forest species published by Carvalho (2003). Three of these species - canafístula, jequitibábranco and ipê-felpudo - are considered promising for lumber, since their wood is valuable, they have acceptable silvicultural performance and are suitable for artificial regeneration programs. Based on the variability observed, they have good potential for genetic selection. Preiskorn et al. (2009) recommended canafistula, capixingui, mutambo, pau-jacaré and angico-branco for use to make crates and charcoal 10 to 15 years after planting. Ipê-felpudo would be suitable after 20 years for sawn lumber, while jequitibá-branco is classified as having high wood density and economic value, with commercial use possible 40 years after planting. The heterogeneous growth of the individuals within species means it will not be possible to establish a common age for cutting each species. As is the case of most other forest species, management will need to involve culling trees that have poor conformation and development.

Two bottlenecks exist regarding recommendation of native forest species for wood production in planted forests: (i) the limited availability of seedlings, which currently come from nurseries focused on production for environmental rehabilitation projects, where diversity is the main criterion for selection of matrixes; and (ii) the small number of published studies on native forest species for use in silviculture (CARVALHO, 2003, 2006, 2008, 2010). This lack of information makes predicting performance in production systems difficult. Greater knowledge of the variability will enable outlining strategies, including selection and improvement, that can contribute to the inclusion of these species in production systems and identification of the most productive arrangements, so as to reduce the risks faced by producers.

The height growth, assessed by the monthly growth rates or by AHI, was greater in the ACS than the SPS, but there was no significant difference between the systems regarding monthly diameter increase rates (Tables 1 and 2). However, the situation was inverted for angico and ipê, which had faster height growth in the SPS, and for canafístula, only for AYI. The growth rate calculated in $\mathrm{cm} / \mathrm{month}$ (Table 1 ) was less sensitive to the differences between the systems than those calculated in AYI (Table 2), due to the greater dispersion of the data used to calculate the monthly than the yearly increases. The greater development observed in the ACS than in the SPS is a common finding in the literature. Trees benefit from the residual fertilization from agricultural cultivation: even though the trees in the SPS received annual fertilization, the amount of inputs was lower than in the ACS.

The growth pace of mutambo reflects the fertility of the site. CATIE (1991) reported the following heights for mutambo 48 months after planting: $4 \mathrm{~m}$ (poor site), $6 \mathrm{~m}$ (medium site) and $8 \mathrm{~m}$ (rich site). In our study, the growth of the mutambo trees in the SPS 48 months after planting was $5.70 \mathrm{~m}$, versus $7.68 \mathrm{~m}$ in the ACS (Table 1). These values are near those found in the

Revista Árvore, Viçosa-MG, v.40, n.4, p.639-648, 2016

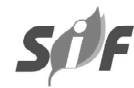


medium and rich site, respectively, by CATIE (1991). Various studies have shown that forest species respond positively to fertilization (IANNELLI-SERVÍN, 2007; CAMPOE et al., 2010), with significant increases in biomass production.

In the ACS, the conventional preparation of the soil implied periodic cutting of the roots in the surface layer, a practice that minimizes competition with the agricultural crop but does not harm the trees. This effect was stronger for the trees in the outside rows (capixingui and mutambo). Both are pioneer species. According to Gonçalves and Mello (2005), pioneer species of the Atlantic Forest biome generally have taproots, which grow deeply in the soil, so these species can be recommended for combination with grasses. In turn, the non-pioneer Atlantic Forest species, represented here by ipê-felpudo, jequitibá-branco and angico-branco, generally have more branched root systems, which emerge from the tree's collar, increasing the possibility of competition for water and nutrients with the associated agricultural crops.

With respect to pests, the technical analysis performed by PESAGRO on the gall sample from the mutambo specimen indicated it was Albugo sp., the agent of white blister rust. Young mutambo trees, grown from seedlings from the same nursery and planted elsewhere in São Carlos presented the same problem. The canafístula trees presented association with a cicada species (Aethalion reticulatum), and also frequently with the stingless bee Trigona spinipes. The impact of these two insects on the tree's development is unknown. Association with these insects was reported in mango trees (VIEIRA et al., 2007), where the authors considered that the presence of the bees increases the consumption of sap by the cicadas, harming the host tree. In our study, the infestation by these two insects declined with time.

\section{CONCLUSION}

The agrisilvicultural system favored the growth both of height and root collar diameter of the species mutambo and capixingui. No effects of the two systems were noted for the other trees (angico, canafístula, ipê, jequitibá and pau-jacaré). The capixigui and mutambo trees presented the best development, independent of the agroforestry system.

Revista Árvore, Viçosa-MG, v.40, n.4, p.639-648, 2016

\section{ACKNOWLEGEMENTS}

We would like to thank Fapesp for supporting the project, and Luiz Augusto de Aguiar for the identification of pests and diseases of mutambo and of canafístula.

\section{REFERENCES}

ANDRADE, C.M.S.; SALMAN, A.K.D.; OLIVEIRA, T.K. Guia ARBOPASTO: manual de identificação e seleção de espécies arbóreas para silvopastoral systems. Brasília, DF: Embrapa, 2012. 345p.

ASSOCIAÇÃO BRASILEIRA DE PRODUTORES DE FLORESTAS PLANTADAS - ABRAF.

Anuário estatístico da Abraf, 2012. Ano base 2011. Brasília: 2012. 150p.

CAMPOE, O.C.; STAPE, J.L.; MENDES, J.C.T. Can intensive management accelerate the restoration of Brazil's Atlantic forests? Forest Ecology and Management, v.259, p.18081814,2010

CARNEIRO, J.G.A. Desbastes florestais.

Revista Floresta, v.4, n.3, p.45-56, 1973.

CARPANEZZI, A.A.; NEVES, E.J.M.; AGUIAR, A.V.; SOUSA, V.A. Espécies lenhosas alternativas para fins econômicos no Paraná. In: SEMINÁRIO DE ATUALIZAÇÃO FLORESTAL, 2.; SEMANA DE ESTUDOS FLORESTAIS, 11., 2010, Irati. Legislação florestal e o Código Florestal Brasileiro. Anais... Irati: UNICENTRO, 2010.9p. Available at:http://anais.unicentro.br/ sef2010/pdf/palestras/Carpanezzi.pdf. Consulted on: Nov. 3, 2010.

CARVALHO, M.M.; CASTRO, C.R.; YAMAGUCHI, L.C.T., ALVIM, M.J.; FREITAS, V.P.; FERREIRA, D.X. Two methods for the establishment of a silvopastoral system in degraded pasture land. Livestock Research for Rural Development, v. 15, n.12, 2003. Available at: http://www.lrrd.org/lrrd15/12/ carv1512.htm. Consulted on: Oct. 7, 2014.

CARVALHO, M.M.; SILVA, J.L.O.; CAMPOS JÚNIOR, B.A. Produção de matéria seca e composição mineral da forragem de seis gramíneas tropicais estabelecidas em um sub-bosque de 
angico-vermelho. Revista Brasileira de Zootecnia, v.26, p.213-218, 1997.

CARVALHO, P.E.R. Espécies arbóreas brasileiras. Brasília: Embrapa Informação tecnológica, Colombo: Embrapa Florestas, 2003. 1039p.

CARVALHO, P.E.R. Espécies arbóreas brasileiras. Brasília: Embrapa Informação Tecnológica; Colombo: Embrapa Florestas, 2006, 2.v. 627p. (Coleção espécies arbóreas brasileiras 2)

CARVALHO, P.E.R. Espécies arbóreas brasileiras. Brasília: Embrapa Informação tecnológica; Colombo: Embrapa Florestas, 2008., 3.v. 592p. (Coleção espécies arbóreas brasileiras 3)

CARVALHO, P.E.R. Espécies arbóreas brasileiras. Brasília: Embrapa Informação tecnológica; Colombo: Embrapa Florestas, 2010. 4.v. 644p. (Coleção espécies arbóreas brasileiras 4)

CATIE Guácimo (Guazuma Ulmifolia) Especie de arból de uso múltiple em América Central. Turrialba: CATIE, 1991. 72p.

DIAS, P.F. Importância da arborização de pastagens com leguminosas fixadoras de nitrogênio. 2005. 140f. Thesis (Doctoral in Phytotechnics) - Universidade Federal Rural do Rio de Janeiro, Seropédica, 2005.

DI RIENZO, J.A.; CASANOVES, F.; BALZARINI, M.; GONZALEZ, L.; TABLADA, C.W. InfoStat versión 2011. Grupo InfoStat, FCA, Universidad Nacional de Córdoba, Argentina. Available at: http://www. infostat. com.ar. Consulte don: April 4, 2014.

\section{EMPRESA BRASILEIRA DE PESQUISA} AGROPECUÁRIA - EMBRAPA. Manual de métodos de análises de solo. 2.ed. Rio de Janeiro: Ministério da Agricultura e do Abastecimento, 1997. 212p.

GONÇALVES, J.L.M.; MELLO, S.L.M. O sistema radicular das árvores. In: GONÇALVES, J.L.M.; BENEDETTI, V. (Ed.). Nutrição e fertilização florestal. Piracicaba: IPEF, 2005. p.219-267.

IANNELLI-SERVÍN, C.M. Caracterização ecofisiológica de espécies nativas da

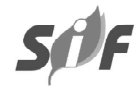

Mata Atlântica sob dois níveis de estresse induzidos pelo manejo florestal em área de restauração florestal no Estado de São Paulo. 2007. 95f. Tese (Doutorado Recursos Florestais) Universidade de São Paulo, Piracicaba, 2007.

JOSE, S.; GILLESPIE, A.R.; PALLARDY, S.G. Interspecific interactions in temperate agroforestry. Agroforestry Systems, v.61-62, n.1, p.237-255, 2004.

KANASHIRO, M.; WADT, L.H.O.; TONINI, H.; RIBEIRO, J.F.; GAIAD. S. Portfolio de Projetos em Recursos Florestais Nativos. Documento síntese. Available at: https:// sistemas.sede. embrapa.br/ideare/pages/ home/principal/principalframes.jsf. Consulted on: July 28, 2014.

KÖPPEN, W. Climatologia. Buenos Aires; Fondo de Cultura Económica, 1948. 479p.

MÜLLER, M.D.; PACIULLO, D.S.C.; MARTINS, C.E.; ROCHA, W.S.; CASTRO, C.R.T.

Desenvolvimento vegetativo de pinhão-manso em diferentes arranjos de plantio em sistemas agrossilvipastoris. Pesquisa Agropecuária Brasileira, v.49, p.506-514, 2014.

NAIR, P.K.R. Classification of agroforestry systems. Agroforestry Systems, v.5, p.97128,1985 .

NUNES, Y.R.F.; FAGUNDES, M.; SANTOS, R.M.; DOMINGUES, E.B.S.; ALMEIDA, H.S.;

GONZAGA., A.P.D. Atividades fenológicas de Guazuma ulmifolia Lam. (Malvaceae) em uma floresta estacional decidual no norte de Minas Gerais. Lundiana, v.6, p.9-105, 2005.

OLIVEIRA, N.M. Estabelecimento de espécies florestais a partir do plantio em diferentes posições do relevo. 2011. 36f. (Monografia apresentada ao Curso de Engenharia Florestal) - Instituto de Florestas da Universidade Federal Rural do Rio de Janeiro, Rio de Janeiro, 2011.

\section{PLANO NACIONAL DE SILVICULTURA COM ESPÉCIES NATIVAS E SISTEMAS AGROFLORESTAIS - PENSAF. Ministerio}

Revista Árvore, Viçosa-MG, v.40, n.4, p.639-648, 2016 
do Meio Ambiente; Ministerio da Agricultura Pecuaria e Abastecimento; Ministerio do Desenvolvimento Agrário; Ministério da Ciência e Tecnologia. Brasília: 2007. 44p

PEREIRA, J.A.A.; BOTELHO, S.A.; DAVIDE, A.C. desenvolvimento de espécies florestais de fast Growth em diferentes condições de sítio Visando a recomposição de matas ciliares. Cerne, v.5, n. 1, p.036-051, 1999.

PREISKORN, G.M.; PIMENTA, D.; AMAZONAS, N.T.; NAVE, A.G.; GANDOLFI, S.; RODRIGUES, R.R.; BELLOTTO, A.; CUNHA, M.C.S. Metodologia de restauração para fins de aproveitamento econômico (RL e áreas agrícolas). In: RODRIGUES, R.R.; BRANCALION, P.H.S.; ISERNHAGEN, I. (Ed.) Pacto pela restauração da Mata Atlântica: referencial dos conceitos e ações de restauração florestal. São Paulo: LERF/ ESALQ: Instituto BioAtlântica, 2009. p. 158-175. Available at: http://www.pactomataatlantica.org.br/ pdf/referencial-teorico.pdf. Consulted on: Nov. 25,2014

RUSCHEL, A.R.; NODARI, E.S.; GUERRA, M.P.; NODARI, R.O. Evolução do uso e valorização das espécies madeiráveis da Floresta estacional decidual do Alto-Uruguai, SC. Ciência Florestal, v.13, n.1, p.153-166, 2003.

SAS Institute Inc. Cary, NC: Software 9.3, 20022010.

SOUCHIE, E.L.; CAMPELLO, E.F.C.; SILVA, E.M.R.; SAGGIN-JÚNIOR, O.J. Arborização de pastagem na região da Mata Atlântica. Floresta \& Ambiente, v. 12, n.2, p.22-27, 2006.
SOUZA JUNIOR, C.N.; BERNARDO, V. Produção de Mudas Nativas com Base na Resolução S.M.A 47/03. In: BARBOSA, L.M. (Coord.) Manual para recuperação de áreas degradadas do estado de São Paulo: matas ciliares do interior paulista. São Paulo: Instituto de Botânica, 2006 Available at: http://

www.ambiente.sp.gov.br/municipioverdeazul/files/ 2011/11/ManualRecupAreas\%20Degradadas.pdf. Consulted on: March 25, 2015.

THORNTHWAITE, C.W.; MATHER, J.R. The water balance. Publications in Climatology. New Jersey: Drexel Institute of Technology, 1955. $104 p$.

VIEIRA, C.U.; RODOVALHO, C.M.; ALMEIDA, L.O.; SIQUIEROLI, A.C.S.; BONETTI, A.M. Interação entre Trigona spinipes FaBRICIUS, 1793 (Hymenoptera:Apidae) e Aethalion reticulatum LINNAEUS, 1767 (Hemiptera:Aethalionidae) em Mangifera indica (Anacardiaceae). Bioscience Jopurnal, v.23, Supp.1, p.10-13, 2007.

VINHOLIS, M.M.B.; NICODEMO, M.L.F.; SANTOS, P.M.; COLA, G.G. Custo da implantação de sistemas de produção silvipastoris em São Carlos, SP. In: ENCONTRO NACIONAL DE ENGENHARIA DE PRODUÇÃO, 30, 2010, São Carlos, SP. Maturidade e desafios da engenharia de produção: competividade das empresas, condições de trabalho, meio ambiente. - Anais... São Carlos: ABEPRO, 2010.

ZIMMER, A.H.; MACEDO, M.C.M.; KICHEL, A.N.; ALMEIDA, R.G. Degradação, recuperação e renovação de pastagens. Campo Grande: Embrapa Gado de Corte, 2012.46p. (Documentos, 189) 